International Journal of Linguistics, Literature and Culture
Available online at https://sloap.org/journals/index.php/ijllc/
Vol. 6, No. 1, January 2020, pages: 14-23
ISSN: 2455-8028
https://doi.org/10.21744/ijllc.v6n1.808

\title{
Designing Problem-Based Learning (PBL) Model for Tourism Vocational Education in 4.O Industry
}

\section{Article history:}

Received: 18 September 2019

Accepted: 27 November 2019

Published: 09 January 2020

\section{Keywords:}

4. O industry; critical thinking;

globalization;

problem-based learning;

vocational education;

\begin{abstract}
The consequences of globalization should be anticipated and adjusted in education, especially the teaching and learning process. The revolution industry of 4.0 has caused some disruption in various aspects including education that is intended for the purpose of learning and innovation skills. The objective of this study is to improve the quality of learning by applying the literacy movement, character values as a provision for life and career skills using the PBL method in tourism vocational education. By applying the descriptive qualitative research method, the data, both primary and secondary, were collected through participant observation in three classes of different study programs in the Tourism Department, Bali State Polytechnic, interview, and literature study. The study found, so far, the implementation of PBL model in the classrooms has been effective. The essence of PBL is regarded as problem-solving activities, which is in the hierarchy of high order thinking skills (HOTS). As a result, the students while giving solutions to problems in various tourism workforce are able to master critical thinking skills, collaboration in teams/social interactions, and soft skills.
\end{abstract}

International journal of linguistics, literature and culture (C) 2020. This is an open-access article under the CC BY-NC-ND license (https://creativecommons.org/licenses/by-nc-nd/4.0/).

\section{Corresponding author:}

I Nyoman Kanca,

Politeknik Negeri Bali, Denpasar, Indonesia.

Email address: nyomankanca@pnb.ac.id

a Politeknik Negeri Bali, Denpasar, Indonesia

b Politeknik Negeri Bali, Denpasar, Indonesia

c Politeknik Negeri Bali, Denpasar, Indonesia 


\section{Introduction}

The educational stakeholders in Indonesia have seen a change in the quality of education in the country and it requires a solution for better improvements. This concern is demanded in order to win tight competition in the globalization era that is marked by several issues, such as the industrial revolution of 4.0, Sustainable Development Goals (Morrar et al., 2017), and 21st-century education must be implemented for educational policy, with the concern of being able to be competitive in the workforce (Łuczewski, 2018; Ginaya et al., 2018; Ginaya et al., 2019). Additionally, there is still an obstacle to implementing equal distribution in the education sector. Therefore, teachers should be sensitized on the issues of the educational shift by improving the quality of education.

The globalization era in the context of education is directed at learning and innovation skills and considering long-term environmental sustainability (Hanushek et al., 2017). There are some learning skills and innovations required, such as the ability to think critically and solve problems, the ability to communicate and collaborate, and creativity and innovation. Whereas the concern for soft skills, learners are reflected in the ecological quotient and characters. Both of these aspects need to be implemented by the role of educators in the learning and school atmosphere. In the current conditions, the government hopes for improvement in human resources by developing vocational education. This is evidenced by a large number of vocational education, the establishment of leadingcompetency-based schools, and the promotion of cooperation with various industries. Thus the competencies of graduates are expected to be in the form of life and career skills (Ambarwati et al., 2019; Sadia et al., 2019; Widana et al., 2018).

In line with this shift in education, the teaching paradigm needs to reconstruct with the approach using scientific methods of a learning process of student-centered. The scientific method involves such activities as observing, asking, trying, reasoning, and communicating. During the learning process, teachers innovate by applying literacy and caring about the environment attitude to students. One of the scientific learning models is problem-based learning (PBL). The learning model needs to be implemented, researched and developed by teachers to improve the quality of learning. Thus teachers need to prepare learning tools with PBL model approach. In fact, learning characteristics in vocational education are dominated by the formation of hard skills and soft skills. While the general characteristics of learning in social science like the tourism sector are practical competence in services and hospitalities. This characteristic of learning is identical to problem-based learning (PBL). This means that students while giving solutions to problems on various tourism job skills are expected to be able to master critical thinking skills, collaboration in teams /social interactions, and soft skills (Erdogan, 2015; Freeman et al., 2014; Handayani et al., 2019).

Problem-based learning (PBL) takes a student-centered approach, usually conducted within small groups. The teacher acts as a facilitator in problem-based learning. The required knowledge and skills are achieved in the process of solving authentic problems (Mathew-maich, 2016). Problem-based learning and inquiry-based learning are not mutually exclusive; rather, problem-based learning involves inquiry strategies. Some objectives of PBL are: (1) helping students develop cognitive flexibility; (2) practicing problem-solving skills as generic skills; (3) self-directed learning which requires high metacognitive ability; (4) practicing collaborative skills and communication skills; (5) increasing intrinsic motivation (Breunig, 2017). Kaouri (2017), list a sequence of PBL classroom practices: (1) analysing a problem scenario and facts in groups; (2) hypothesizing and explaining how to solve the problem; (3) dividing up the learning issues within the group, learning new knowledge which is needed to solve the problem; (4) returning to the problem (5) repeating the learning cycle until the problem is successfully solved; (6) reflection and abstraction.

A meta-analysis study done by Ertmer \& Glazewski (2015), generates some interesting results showing the general effects of PBL on knowledge and skills, and factors moderating the effect of PBL. Ertmer and Glazewski elaborate on the general effects of PBL: (1) The effect of PBL on skills could be positive across students' expertise levels; however, the effects of PBL on content knowledge might differ significantly based on students' expertise levels and knowledge base. Age-related characteristics such as students' metacognitive skills, social-cognitive and affective ability need to be addressed. For example, students with a low level of prior knowledge may be overwhelmed when asked to apply the newly encountered knowledge; (2) although students might learn slightly fewer facts and less content knowledge in a PBL environment, the knowledge they acquire is much more elaborate; thus, students in PBL might perform better in retention and transfer of the knowledge in larger contexts; (3) different forms of assessment might yield different results due to the complex structure of achievement; thus, a range of

Ginaya, G., Kanca, I. N., \& Sri Astuti, N. N. (2019). Designing problem-based learning (PBL) model for tourism vocational education in 4.o industry. International Journal of Linguistics, Literature and Culture, 6(1), 14-23. 
diversified assessment strategies are needed to gain a clear picture of students' knowledge and skills achievement in PBL.

PBL is a pedagogic focused on active students (Phungsuk et al., 2017; Hirca, 2011), in a learning environment in the form of problem-solving with analytical and data skills. However, the focus of PBL is not in resolving the problem, but the process of gaining experience, social interaction and communication, and group collaboration as professional competencies. With the problem's identification through analysis and data-based process, students are expected to be able to make and present reports and then innovations will emerge. PBL can also be integrated with character values to prepare life and career skills, for instance, religious, curious, communicative, creative, discipline, caring for the environment and being responsible (adaptation from the Ministry of National Education, 2011). Broadly speaking, it consists of personal and social skills (El Mawas \& Murtean, 2018). Moreover, PBL can implement literacy, namely information, reading, media, and ICT (Turiman et al., 2012).

\section{Materials and Methods}

This research was conducted by applying a descriptive qualitative method. The sources and types of data are including both primary and secondary data. The primary data was obtained directly in the field through participant observation to three different classes of Travel and Tourism, Hotel, and Business Management program Studies in Tourism Department, Bali State Polytechnic and interview techniques (Denis \& Loomis 2007; Ritchie et al., 2013; Macías et al., 2018). Whereas, the secondary data was collected through literature review technique (Bungin, 2001). The three classes were selected based on purposive sampling technique. The additional information to complete the data which is considered still insufficient was done by using a snowball sampling technique as one of the nonprobability sampling techniques in qualitative research by doing a tracer study. The tracer study was done for the purpose of looking for graduates as key informants in field research that helps researchers find other key informants or open access to respondents to be studied (Bungin, 2001). This sampling technique is applied for the purpose of examining those which are related to the implementation of PBL model in designing learning materials in the context of tourism both services' and hospitalities' industries.

The data, subsequently, were analyzed with qualitative descriptive methods based on an inductive methodological paradigm that departs from specific to general principles (Masun et al., 2006). Additionally, by applying a descriptive analysis method, the data that has been collected in the form of implementing PBL by describing information obtained from triangulation data collection provided by stakeholders, namely by comparing data obtained from interviews with the stakeholders, observations made by researchers and documents related to the problem. So that later the results obtained can be tested for validity and can be described or explained in the discussion. The results of the study are presented in formal and informal methods. According to Sugiyono (2010), the method of informal presentation is to present the results of the analysis with a description or regular words, while the method of formal presentation is the formulation with signs and symbols. Hammond \& Welington (2012), state that the symbols or signs are used to present or formulate the results of the analysis so that the meanings of rules and concepts, inter-rule and concept relations, and the rules and concepts of peculiarities can be identified and understood.

\section{Results and Discussions}

This study concerns with analyzing the qualitative data from the answer to the research question from the whole observation, in-depth interview, and literature review of designing PBL model in vocational education. The research questions in this study were concerned about how PBL model is able to motivate the students of the Tourism Department, Bali State Polytechnic in mastering English. This model of learning can be as an opportunity for enhancing the graduates' quality competence. Additionally, all the potential teaching and learning skills possessed by teachers and students in this digital era require to be developed as an endeavor to pursue the process of gaining experience, social interaction and communication, and group collaboration as professional competencies. The endeavor requires a distinctive policy of vocational education in this industry 4.0 era in order for the graduates as the learning output to be competitive in the workforce. All of the aforementioned issues are discussed in this part. 


\subsection{Conventional Teaching Method Versus Problem-Based Learning Model}

The teaching-learning process in vocational colleges such as the Bali State Polytechnic seeks to make students master the elements of competence in accordance with the performance demanded by the industry. This requires integrated learning between related courses when referring to the application of a curriculum based on national qualification frameworks or KKNI. Currently, the study in the Tourism Department consisting of three courses, namely Tourism and Travel, Hotel, and Tourism Business Management Study Programs has adopted the KKNIbased curriculum. However, the results of a search study with observations and interviews to the lecturers in three study programs, Bali State Polytechnic show that English language study for college students is not optimal and integrated with other subjects, such as the course of Tour Guiding Technique, Front Office, Food and Beverage Service, and Organizing Events This is due to the lack of supporting factors, such as learning models, teaching books, learning time, and student motivation.

Based on the results of observations and interviews to the management of majors and lecturers in the Tourism Department, there are several obstacles to integrating English courses with other courses, among which are 1) learning models that applied during this time are conducted in their respective classes or in the laboratory without involving two distinct teaching lecturers. 2) A teaching book that still uses text-based learning models. 3) Students are still less motivated to learn. 4) The perception of the students that were interviewed about English learning today also stated that English language learning needs to be integrated with the core subject of each program Studies using communication in English. A total of $95 \%$ of students said learning English courses should be integrated with core courses so that learning becomes more contextual so that the students do not experience the learning situation as it is shown in figure 1.

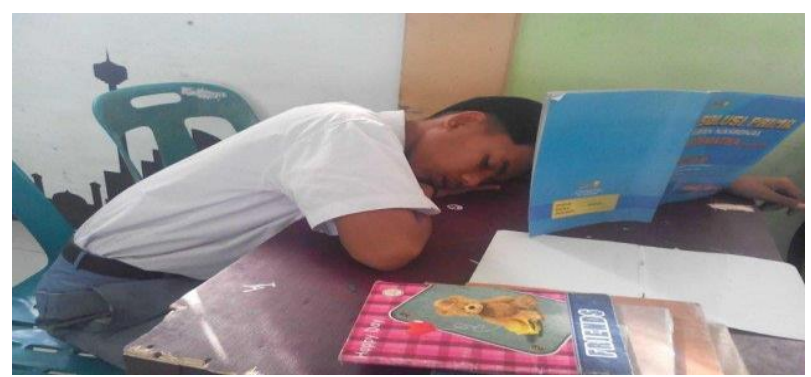

Figure 1. A condition of the classroom with the unmotivated student in learning

The condition of learning in figure 1 can happen in one's class if students get bored with the conventional method of teaching like lecturing, which is teacher-centered. The critic of this method of learning rises into questions: are the students engaged? Are they participating? Starting from the problems faced by lecturers and management of the Tourism Department, and the responses, perceptions, and suggestions provided by the Tourism Department students, the development of the English language learning model with an approach of problem-based learning (PBL) in Tourism Department very need to be developed. As an excellent applied research education in the field of vocational education, the goal to be achieved in this development research is (1) develop an English learning model with a problem-based approach that suits the needs of students in Tourism Department, Bali State Polytechnic, (2) to provide a validated English language learning module for Tourism Department students, and (3) implement an English learning model with an approach Problem-based to the students of Tourism Department, Bali State Polytechnic. This urgent research is done to create innovative English language learning in tourism majors so that graduates are competent and ready to use in the tourism industry. This can be achieved when learning contextual English is integrated between language and content in the field of tourism through the support of several aspects of learning, such as innovative learning methods, teaching materials, teaching modules, tools assessment, learning syntax, and other teaching aids based on problem-based learning methods (PBL) to build student critical thinking levels or "HOTS" (higher-order thinking skills)

\subsection{How to Inspire Students for Solving Problems in PBL Model}

The problem-based learning model emphasizes student-centered learning that demands active students and in a learning environment in the form of problem-solving with analytical and data skills. Students work with classmates

Ginaya, G., Kanca, I. N., \& Sri Astuti, N. N. (2019). Designing problem-based learning (PBL) model for tourism vocational education in 4.o industry. International Journal of Linguistics, Literature and Culture, 6(1), 14-23. https://doi.org/10.21744/ijllc.v6n1.808 
to solve complex and authentic problems that help develop content knowledge as well as problem-solving, reasoning, communicating, and self-assessment skills. On the other hand, teacher-coaches them or his/her role as a learning facilitator. The steps in PBL learning can be seen in table 1.

Table 1

Steps in PBL learning

\begin{tabular}{lll}
\hline Step 1 & Step 2 & Step 3 \\
\hline Understanding the Problem & Explore/Investigate & Resolve the Problem \\
Meet the problem & Gather information & Determine the best fit solution \\
Know/Need to Know & Share information & Present the solution \\
Define the problem statement & Generate possible solution & Debrief the problem \\
\hline
\end{tabular}

The competency in this research using the PBL method is activities in the context of a job in the tourism industry. The complexity of the tourism job competency increases the thinking ability and good group collaboration because the activities carried out include two aspects, language, and content. Through these competencies, students will have knowledge of certain professions. The two learning aspects require synchronized learning activities in order for the process of teaching and learning is contextual. Prior to the implementation of learning, in preparing PBL model, researchers observed and interviewed the services' and hospitality industry regarding common competences. From the competencies obtained, they are analyzed for the learning stage. The learning stages can be carried out in some cycles of learning. Researchers, in the first cycle, gave problems that are in line with the objective that students should be adapting to PBL stages and the mindsets analysis should not be much different. In the following cycle, students are given unstructured problems. Learning tourism industry competency is categorized to be successful there is an increase in the output with class completeness of $80 \%$ from the total number of students. In addition, evaluation is needed on the implementation of literacy and life skills and career skills that are integrated with character values. Learning and innovation skills in PBL involve three aspects, namely literacy, hard, and soft skills as it is showed in table 2 .

Table 2

Learning and innovation skills in PBL

\begin{tabular}{lll}
\hline & \multicolumn{2}{c}{ Skills } \\
\hline Literacy & Hard & Soft \\
\hline Information Literacy & Work preparation & Communicative \\
Reading Literacy & Work process & Creative and Care for the environment \\
Media and ICT Literacy & Work result & Discipline and Responsible \\
\hline
\end{tabular}

The results that are obtained during the learning process of the tourism industry competency with the PBL method should be based on learning and innovation skills in PBL as in table 2. It is necessary to discuss the aspects of action and the success percentage based on assessment indicators. Each aspect as a whole was considered to be successful when it was at least in the "good enough" category. The criteria to be assessed consist of communicating tasks and using information sources on information literacy, the suitability of sources on reading literacy, and usage in ICT and media literacy. From the analysis, during the action, it will be analyzed the students' teamwork for collaborative learning.

\subsection{Designing Problem-Based Learning Model for Tourism Subject Course}

In designing the PBL model for the classroom tourism subject course it is best to consider Bloom's Taxonomy as a framework for teaching thinking. Instead of teaching students to recall facts Bloom's objective was to support higher forms of thinking in education, such as analyzing and evaluating. The cognitive domain of Bloom's Taxonomy comprises of abilities and skills within stated in six groups which are knowledge, comprehension, application, analysis, evaluation, and synthesis. Each of the behavior needs to be learned before the next one can take place. The teacher should use this useful information in planning their lesson, therefore, learning mastery is required before students do a certain task. For example, guided presentations like laboratory sheets are not needed when they 
execute their learning tasks. Moreover, Bloom's Taxonomy has been revised by Dettmer (2005), in order to adequately cover the more outcome-focused modern education objectives. This was done by changing the names of the groups from nouns to active verbs. They also had inverted evaluation and synthesis as the highest domain order as it is shown in Figure 2.

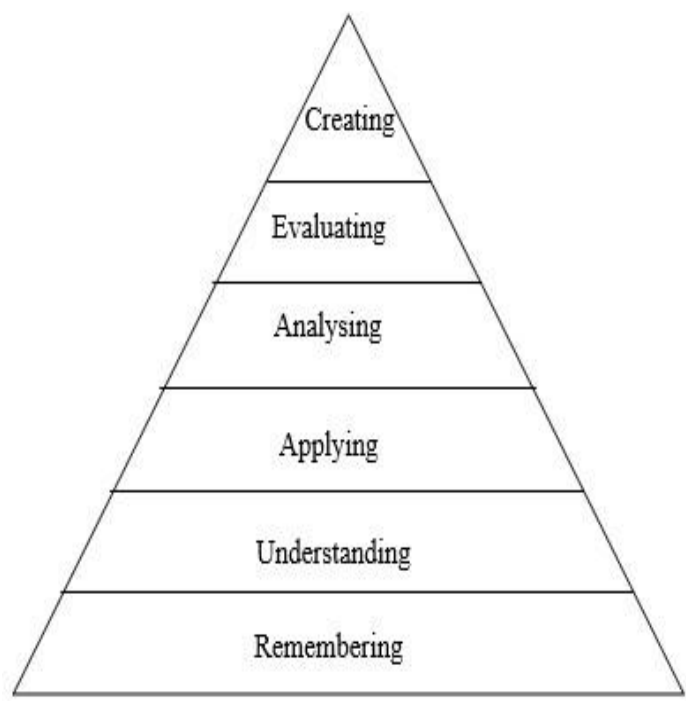

Figure 2. Revised taxonomy bloom

The prominent concern of vocational education nowadays is to cultivate its students to be competitive. Teachers are demanded to emphasize thinking skills in the teaching processes so that it can be applied from classroom situation to a variety of real-life contexts. Critical thinking can arise at any time in the process of assessment, decision, or problem resolution in general. Whenever someone tries to know what to believe, what needs to be known for its reasons. The process of its processing can be done through reflective activities, such as reading, writing, speaking and listening. Additionally, to improve and develop the creative thinking skills of learners, good learning activities to do by the teacher is to improve the conducive learning environment in order to support the development of creativity that is a learning environment that directly provides opportunities for learners to think openly and flexibly without any fear or shame. For example, teachers give an overview of the established learning situation should facilitate discussion, encourage learners to give ideas and opinions. Some samples of learning activities in PBL model which are leveled in accordance with the essence of HOTS can be seen below.

\section{Model 1. The Farmer's Problem}

A farmer went to the market and bought a dog, a goat, and some vegetables. On his way home, he had to cross a river, but there was no bridge. So he had to take his purchases across the river in a small canoe. This canoe was so small that he could only take one of his purchases with him. First, he wanted to take the vegetables, but the dog and the goat began to fight. Then, he tried to take the dog, but the goat began to eat the vegetables. So, he took the goat first. This was alright because the dog would not eat the vegetables. But, what did the farmer do next?

\section{Model 2. The Family Holidays}

This is the last day for a family who spends their holiday in Bali before they go back to their country. They don't want to be separated from each other. Make a tour itinerary that suits all their needs.

Doris (90 years old): She wants to visit Besakih Temple (75 Km from the hotel)

David (20 years old): He wants to stay in a hotel for swimming and sunbathing on the beach. He hates shopping.

Marry (40 years old): She wants some shopping to buy souvenirs for her friends.

John (30 years old): He wants to do some adventure tours like white water rafting, elephant safari, and mountain cycling.

Ginaya, G., Kanca, I. N., \& Sri Astuti, N. N. (2019). Designing problem-based learning (PBL) model for tourism vocational education in 4.o industry. International Journal of Linguistics, Literature and Culture, 6(1), 14-23. 
Model 3.

Work in groups of four. Two students are the judges. Two students are the chefs.

Judges: Make a list of three ingredients for the chefs to use. You will decide which chef to create the best recipes.

Chefs: Think of a recipe using the three ingredients the judges give you and other basic ingredients. Name the recipe and describe how to make it.

Change role and try the role play again

Model 1 is the first problem solving that is good for motivating students, especially to attract their learning interests. In addition, they can also practice using simple past tense and some vocabulary. The students can work in a small group to find a solution for the farmer problem. Various answers may arise, but it doesn't matter whether they are correct or not the most important thing is that they try to express their ideas and they are able to practice their English. Finally, one group of the students can give the best solution or if no one can give the best solution, the teacher can give the solution. This activity can be followed up by inviting the students if they can make other similar problems to be solved. The second model is a more complicated problem for the students to find their solution. They also can work in a small group and similar to the first model various answers are accepted and they can be ranked which one is the best answer. While the third model is the most difficult one where the students in turn to be judges and chefs. Starting from the judges they should be able to give three ingredients to the chefs for making a recipe and the chefs will be able to create a recipe and name it based on the three main ingredients given and other basic ingredients. At last, the judges will decide which recipe is the best. In more real practice, the students can video this problem solving activity so that beside they practice English as a foreign language the core competency of food and beverage operation, they also can practice the media and ICT literacy skill in making video by utilizing their smartphones starting from shooting, editing, until the video is uploaded to social media like YouTube and they can share the link to be viewed and subscribed.

\section{Conclusion}

The 4.0 education Era, the role of the teacher in vocational education is important and Strategic. In this era, a teacher must be able to develop learning methods that adapt to the needs of the learners and adapt to the advancement of technology. In order to produce graduates who have high competitiveness and are ready to compete need a teacher who has a core competency of science (core competence) strong, has soft skills, critical thinking, creative, communicative and able to collaborate well with students. Teachers should be able to adapt to contemporary developments. Learning methods applied can no longer apply conventional ones, teachers must be able to follow the development of technology so as to produce highly competitive graduates. Teachers also play a role to spread passion and inspire students, teachers also become friends for students, and teachers also have to model and character.

One of the keys to facing future challenges is innovation creation. The development of crystalline and creative thinking skills and solving problems related to the lives of learners is important. This realization needs to be a foothold in promoting contextual learning. Therefore, teachers need to do, seriously designing the learning based on the premise of the learning process. More innovative demands in the learning process and hope for the development of sharp thinking in relation to the quality of graduates. If the teacher is still using conventional teaching methods, the curriculum is as good as not being able to form qualified graduates.

\section{Conflict of interest statement and funding sources}

The authors declared that they have no competing interests.

\section{Statement of authorship}

The authors have a responsibility for the conception and design of the study. The authors have approved the final article. 
Acknowledgments

The authors are very grateful to some parties who have given contributions and encouragements in completing this article. Particular thanks are owed to Kementerian Riset, Teknologi dan Pendidikan Tinggi of Republic Indonesia who funded the authors' research in the scheme of DRPM-PTUPT.

Ginaya, G., Kanca, I. N., \& Sri Astuti, N. N. (2019). Designing problem-based learning (PBL) model for tourism vocational education in 4.o industry. International Journal of Linguistics, Literature and Culture, 6(1), 14-23. https://doi.org/10.21744/ijllc.v6n1.808 


\section{References}

Ambarwati, D., Suyatna, A., \& Ertikanto, C. (2019). The Effectiveness of Interactive E-Book for Self-Study and Increasing Students' Critical Thinking Skills in Electromagnetic Radiation Topic. In Journal of Physics: Conference Series (Vol. 1155, No. 1, p. 012050). IOP Publishing.

Breunig, M. (2017). Experientially learning and teaching in a student-directed classroom. Journal of Experiential Education, 40(3), 213-230. https://doi.org/10.1177\%2F1053825917690870

Bungin, B. (2001). Metodologi penelitian kualitatif. Jakarta: PT Raja Grafindo Persada.

Denis, M., \& Loomis, J. M. (2007). Perspectives on human spatial cognition: memory, navigation, and environmental learning. https://doi.org/10.1007/s00426-006-0079-X

Dettmer, P. (2005). New blooms in established fields: Four domains of learning and doing. Roeper review, 28(2), 70-78. https://doi.org/10.1080/02783190609554341

El Mawas, N., \& Muntean, C. (2018). Supporting lifelong learning through development of 21 st century skills.

Erdogan, T. (2015). Research trends in dissertations on PBL: A content analysis study. Procedia-Social and Behavioral Sciences, 197, 308-315. https://doi.org/10.1016/j.sbspro.2015.07.142

Ertmer, P. A., \& Glazewski, K. D. (2015). Essentials for PBL implementation: Fostering collaboration, transforming roles, and scaffolding learning. Essential readings in problem-based learning, 89-106.

Freeman, S., Eddy, S. L., McDonough, M., Smith, M. K., Okoroafor, N., Jordt, H., \& Wenderoth, M. P. (2014). Active learning increases student performance in science, engineering, and mathematics. Proceedings of the National Academy of Sciences, 111(23), 8410-8415. https://doi.org/10.1073/pnas.1319030111

Ginaya, G., Rejeki, I. N. M., \& Astuti, N. N. S. (2018). The effects of blended learning to students'speaking ability. International journal of linguistics, literature and culture, 4(3), 1-14.

Ginaya, G., Somawati, N. P., Aryana, I. N. R., \& Putra, I. M. A. (2019). Improving Students' Communicative Competence through Inductive Method Using Authentic Materials. Journal of Language Teaching and Research, 10(5), 1080-1088. http://dx.doi.org/10.17507/jltr.1005.22

Hammond, M., \& Wellington, J. (2012). Research methods: The key concepts. Routledge.

Handayani, N. D., Mantra, I. B. N., \& Suwandi, I. N. (2019). Integrating collaborative learning in cyclic learning sessions to promote students' reading comprehension and critical thinking. International Research Journal of Management, IT and Social Sciences, 6(5), 303-308. https://doi.org/10.21744/irjmis.v6n5.777

Hanushek, E. A., Schwerdt, G., Woessmann, L., \& Zhang, L. (2017). General education, vocational education, and labor-market outcomes over the lifecycle. Journal of Human Resources, 52(1), 48-87.

Hirca, N. (2011, April). Impact of problem-based learning to students and teachers. In Asia-Pacific Forum on Science Learning \& Teaching (Vol. 12, No. 1).

Kaouri, Z. (2017). Evaluating the use of ICT in education: Factors affecting teaching with technology. In Proceedings of the International Conference on Information, Communication Technologies in Education (pp. 449-462).

Łuczewski, M. (2018). Ruin and Restoration: On Violence, Liturgy and Reconciliation. https://doi.org/10.1080/13537903.2018.1473203

Macías, E. I. P., Cedeño, H. A. C., \& Chávez, G. M. R. (2018). Importance of Improving Resilience in TeachingLearning Process of Students with Disabilities. International Research Journal of Management, IT and Social Sciences, 5(2), 120-128.

Masun, H., Rania, L., \& Ghias, B. (2006). Adaptive web-based educational system using neural networks in EFL Course. In 2006 2nd International Conference on Information \& Communication Technologies (Vol. 1, pp. 622625). IEEE.

Matthew-Maich, N., Martin, L., Hammond, C., Palma, A., Pavkovic, M., Sheremet, D., \& Roche, C. (2016). Nursing students' perceptions of effective problem-based learning tutors. Nursing standard,31(12). https://doi.org/10.7748/ns.2016.e10318

Morrar, R., Arman, H., \& Mousa, S. (2017). The fourth industrial revolution (Industry 4.0): A social innovation perspective. Technology Innovation Management Review, 7(11), 12-20.

Phungsuk, R., Viriyavejakul, C., \& Ratanaolarn, T. (2017). Development of a problem-based learning model via a virtual learning environment. Kasetsart Journal of Social Sciences, 38(3), 297-306. https://doi.org/10.1016/j.kjss.2017.01.001

Ritchie, J., Lewis, J., Nicholls, C. M., \& Ormston, R. (Eds.). (2013). Qualitative research practice: A guide for social science students and researchers. sage. 
Sadia, I. K., Ginaya, G., Kanah, K., Dyah, W., \& Nadra, N. M. (2019). Video-based observation in master chef role-plays. International journal of linguistics, literature and culture, 5(6), 78-91. https://doi.org/10.21744/ijllc.v5n6.772

Sugiyono, P. D. (2010). Metode penelitian pendidikan. Pendekatan Kuantitatif.

Turiman, P., Omar, J., Daud, A. M., \& Osman, K. (2012). Fostering the 21st century skills through scientific literacy and science process skills. Procedia-Social and Behavioral Sciences, 59, 110-116. https://doi.org/10.1016/j.sbspro.2012.09.253

Widana, I. W., Parwata, I. M. Y., Parmithi, N. N., Jayantika, I. G. A. T., Sukendra, K., \& Sumandya, I. W. (2018). Higher order thinking skills assessment towards critical thinking on mathematics lesson. International Journal of Social Sciences and Humanities, 2(1), 24-32. https://doi.org/10.29332/ijssh.v2n1.74

\section{Biography of Authors}

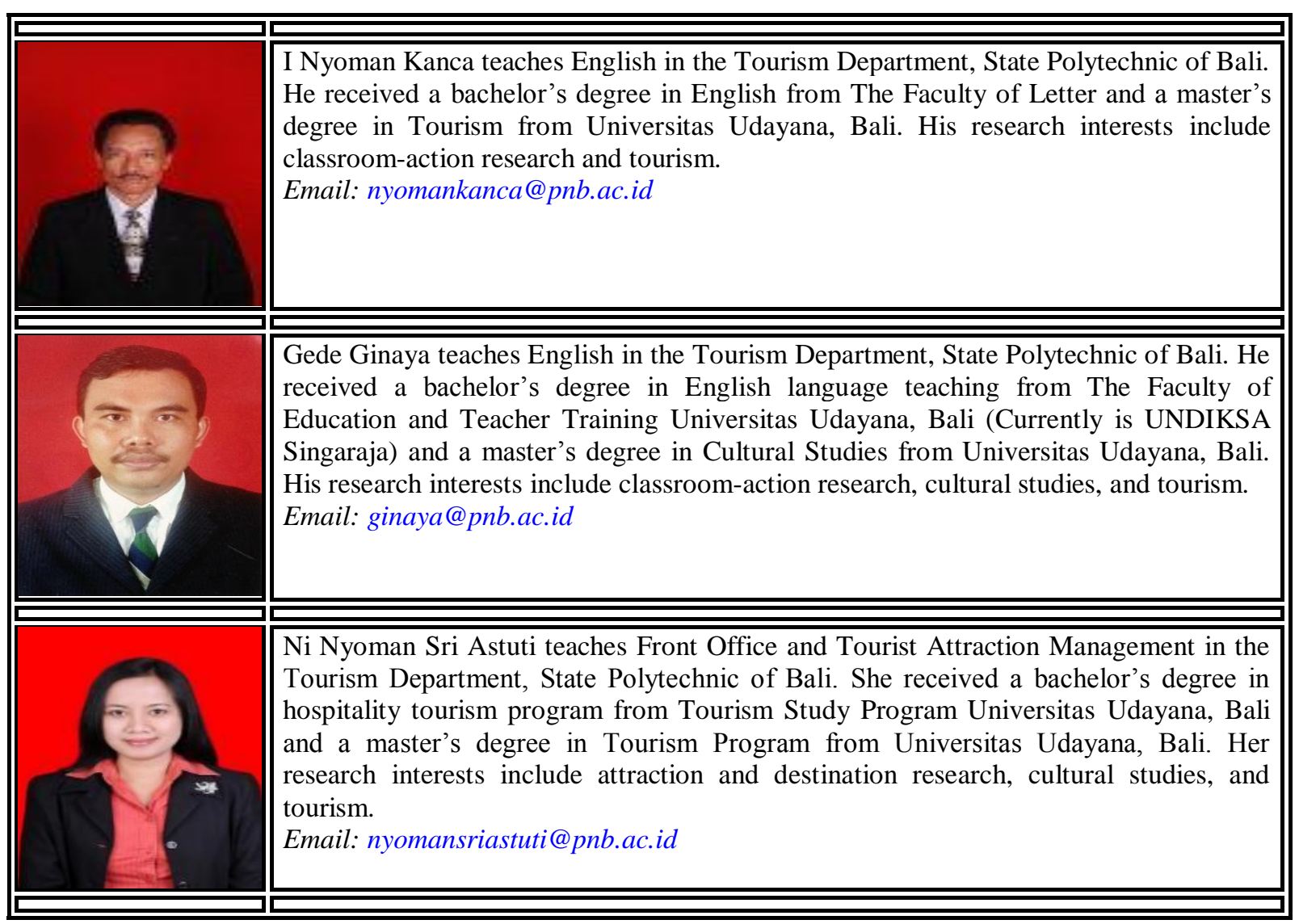

Ginaya, G., Kanca, I. N., \& Sri Astuti, N. N. (2019). Designing problem-based learning (PBL) model for tourism vocational education in 4.o industry. International Journal of Linguistics, Literature and Culture, 6(1), 14-23. 